\title{
PENGARUH CURRENT RATIO, DEVIDEN PAYOUT RATIO DAN RETURN ON EQUITY TERHADAP PRICE TO BOOK VALUE SERTA DAMPAKNYA TERHADAP HARGA SAHAM PADA INDUSTRI MAKANAN
}

(Perbandingan antara perusahaan ynag terdaftar di Bursa Efek Jakarta dan persuahaan yang terdaftar di Bursa Efek Malaysia periode 2011 - 2016)

\author{
Darul Fahmi \\ Fakultas Ekonomi, Universitas Pamulang \\ darul.bta@gmail.com
}

\begin{abstract}
Abstrak
Penelitian ini memiliki tujuan agar peneliti bisa memahami apakah ada pengaruhnya variabvel CR (Current Ratio), DPR (Deviden Payout Ratio) dan ROE ('Return On Equity') terhadap PBV ('Price to Book Value') serta dampaknya terhadap HS ('Harga Saham') pada perusahaan industri makanan yang terrgister di BEJ dan Bursa Malaysia dengan periode pengamatan 2011-2016. Dalam penelitian ini teknik pengambilan sampel menggunakan teknik purposive sampling kemudian ditetapkan berbagai kriteria. Atas dasar ketentuan dan kriteria yang ditetapakan tersebut maka pada Negara Indonesia didapatkan 6 perusahaan dan pada Negara Malaysia 5 perusahaan yang layak dan memenuhi syarat untuk dijadikan sampel.

Didalam penelitian ini pengujian hipotesis menggunakan alat uji analisis regresi linear berganda dengan menggunakan program Eviews versi 8.0. Populasi dalam penlitian ini adalah perusahaan industri makanan yang tercatat di BEJ. Sesuai dengan daftar yang trcantum dalamm dalam Capital Market Dirctory (ICMD) tersebut diketahui bahwa ada 14 perusahaan makanan dan minuman yang listing di BEJ dan didalam Bursa Malaysia didapat 10 persahaaan. Pengambilan samapel dalam penelitian ini dengan menggunakan metode purposive sampling. Sejumlah 36 laporan tahunan perusahaan perusahaan Indonesia dan 30 laporan tahunan perusahaan Malaysia (masing-masing selama 6 tahun) diatas telah diolah dan untuk analisis dengan alat analisis metode "regresi linier berganda" dengan menggunakan program Eviews Versi 8.0.

Setelah diuji dengan alat Uji Hipotesis. hasil penelitian yang dilakukan pada perusahaan Indonesia didapatkan data bahwa secara Uji Parsial (uji t) variabel CR, $D P R$ dan ROE tidak mempunyai pengaruh yang signifikan terhadap variabel PBV, tetapi dengan pengujian secara bersama $C R, D P R$ dan ROE justru berpengaruh dan signiifikan terhaadap vaariabel PBV yang dibuktikan dengan nilai probabilitas $0.0000<0.05$. Sedangkan pada perusahaan Malaysia dari hasil Uji Parsial (uji t) untuk variabel $C R$ dan ROE memeunyai pengaruh yang signifikan terhadap PBV sedangkan variabel DPR dari hasil uji Parsial (uji t) tidak memeiliki pengaruh yaang signifikan terhaadap PBV. Selanjutnya pada Perusahaan Indonesia hasil pengujian secara simultan didapat hasil $F$ hitung 14,55898 > F tabel 2,69 dengan nilai probabilitas 0.000000 , ini berarti variabel $C R$, DPR dan 'ROE bepengaruh yaang signifiikan terhadap PBV. Hasil Koefisien Determinasi (R2) pada perusahaan Indonesia sebesar 0.8111810 atau $81.18 \%$ artinya kemampuan variabel independen dapat menjelaskan atau mempengaruhi varibel dependen senilai $81,18 \%$ sedangan selebihnya 18,82\% dijelaskan oleh variebel lain diluar varaibel yang diteliti. Sedangkan pada perusahaan Malaysia hasil uji secara simultan nilai $F$ hitung
\end{abstract}


$12.27125>$ dari nilai $F$ tabel 2.76 dengan nilai probabilitas 0.000003,sehingga didapat kesimpulan bahwa secara simultan variabel CR, DPR dan ROE memepunyai pengaruh yang signifikan terhadap variabel PBV. Nilai R2 (Koefisien Determinasi) sebesar 0.796105 atau $79.61 \%$, artinya kemampuan variabel independen dapat menjelaskan atau mempengaruhi variabel dependen sebesar 79,61\% sedangan sisanya 20,39\% dijelaskan oleh faktor/variabel lain diluar yang sedang diteliti. Kemudian uji variabel PBV terhadap harga saham pada Perusahaan Indonesia menunjukan hasil bahwa variabel PBV memepunyai pengaruh yang signifikan terhadap variabel Hrga Saham yang ditunjukan dengan nilai probabilitas $0.0000<$ 0,05. < 0.05. begitu juga dengan perusahaan Malaysia PBV berpengaruh secara signiifikan terhadap variiabel Haraga Saham yang ditunjukan dengan nilai probabilitas $0.000<0,05$

Kata kunci : Harga Saham, PBV (Price to Book Value), CR (Current Ratio), DPR (Deviden Payout Ratio), ROE (Return On Equity)

\section{PENDAHULUAN}

Berinvestasi adalah suatu keputusan yang penting dalam kegiatan bisnis, karena didalam kegiatan penanaman modal atau investasi seorang investor menanamkan modalnya kepada suatu proposal investasi yang realisasi keuntungannya hanya bisa terealiasasi dimasa depan (Van Horne, 2005:108). Oleh karena itu seorang investor perlu mengevaluasi dalam hubungan imbal hasil yang diharapkan dan resiko yang mereka miliki. Salah satu komponen yang digunakan dalam evaluasi financial yang dilakukan oleh seorang investor/penanam modal dalam mempertimbangkan untuk memeutuskan investasi yang dipertimbagkan adalah Laporan Keuangan (financial Statement). 'Menurut PSAK No. 01 (revisi 2009) “Laporan Keuangan (financial Statement) adalah penyajian data keuangan yang terstruktur dari posisi keuangan dan hasil kinerja dari suatu entitas atau perusahaan”. Didalam Lapooran Keuaangan terekam peristiwa / kejadian bisnis dalam unit moneter sehingga mencerminkan kegiatan performa perusahaan tersebut selama beroperasi.

Perkembangan dari posisi dan kondisi keuangan perusahaan memuat makna atau arti yang amat penting bagi sebuah perusahaan. Dalam mengamati dan memperhatikan kondisi sehat atau tidak sebuah perusahaan, tidaklah mudah dan tidak cukup juga hanya dengan melihat secarav kasat mata saja, misalnya hanya melihat gedung yang bagus, atau cabangnya banyak ekspansinya luas. Faktor yang penting untuk melihat sehat atau tidaknya 
sebuah perusahaan terleetakpada unsur laporan keuangan yang bisa dipelajari dan dievaluasi bagaimanakah manajemen menjalankan kebijakan perusahaan, apa sduah sesuai ketentuan apa belum, karena tidak sedikit perusahaan yang bangkrut atau gulung tikar dikarenakan atau dipengaruhi oleh faktor keuangan yang tidak sehat.

Menurut pendapat ahli yang lain alat untuk mengukur faktor-faktor yang menentukan kesehatan keuaangan perusaahaan dapat dilakukan melakukan analisa perhitungan rasio-rasio keuangan. Untuk melakukan analisa terhadap laporan keuangan maka deiperlukan perbandingan rasio-ratio untuk menggambarkan kondisi tertentu. Rasio-rasio perbandingan unsur laporan keuangan dapat kalkulasi berdasarkan data angka yang ada dalamm neraca sajaa, atau hanya daalam lapooran laba rugi atau kobinasi dalam laporan laba ruugi dan neraca. Menurut (Suad Husnan, 2002 : 69) "Setiap perbandingan unsur Laporan Keuangan tentu bisa saja merumuskan suatu rasio tertentu yang dapat mencerminkan kondisi tertentu pula". Sedangkan menurut Van Horn (2002 : 234), "Rasio keuangan adalah alat yang digunakan untuk menganalisis kondisi keuangan dan kinerja perusahaan. Kita menghitung berbagai rasio karena dengan cara ini kita bisa mendapat perbandingan yang mungkin akan berguna daripada berbagai angka mentahnya sendiri”. Salah satu bagian/unsur Rasio Liquiditas ynag digunakan dalam penelitian ini adalah 'Current 'Ratio atau rasio lancar. Rasio Lancar adalah :"rasio yang digunakan dalam mengetahui dan mengukur kemampuan perusahaan dalam membayar seluruh hutang/kewajiban jangka pendeknya dengan menggunakan seluruh aktiva lancar yang dimiliki oleh perusahaan".

"Rasio berikutnya adalah Dividen Payout Ratio yaitu untuk mengukur deviden yang dibagikan dengan laba/keuntungan yang disediakan untuk pemegang saham umum" Owain, et all (2008). Jadi Deviden Payout Ratio yaitu memperbandingan keuntungungan yang dibagikan kepada pemegang saham umum (deviden) dari laba yang diperoleh perusahaan. Pendapat ahli yang lain adalah pendapat Hanafi dan Halim (2009:86) "yaitu mengemukakan bahwa Deviden Payout Ratio merupakan rasio pembayaran deviden yang 
melihat earnings (pendapatan) yang dibayarkan kepada pemilik modal (pemegang saham) berupa deviden".

Bagian dari profitability perusahaan yang pada penelitian ini digunakan ROE ('Return On Equity') yaitu rasio untuk mengukur daya tau kekmapuan suatu entitas/ perusahaan untuk menghasilkan laba dengan menggunakan modal saham tertentu, biasanya rasio ini digunakan sebgai tolak ukur dari sisi pandang pemegang saham. ROE ('Return On Equity') merupakan perbandinagn antara keuntungan bersih setelah dikurangi pajak (Earning After Tax = EAT) dengan dengan modal yang diinvestasikan oleh pemilik saham kedalam perusahaan. Rasio ini menggmbarkan bagaimana perusahaan mampu untuk mengahasilkan laba dari investasi modal didasarkan pada nilai buku dari pemilik saham dan acapkali pakai guna memperbandingkan antara bebeapa perusahaan atas peluang peluang unutk berinvestasi dengan manajemen pengelolaan biaya yang efektif.

Variabel $\mathrm{Y}$ yang digunakan didalam penelitian adalah Price to Book Value(PBV). Menurut Husman S dan Pudjiastuti (2006:258) "Price to Book Value (PBV) merupakan perbandingan antara harga pasar saham dengan nilai buku saham”. Rasio ini pada umumnya mencapai lebih dari satu kali lipat, jikalau harga dipasar jauh diatas dari nilai bukau, maka ini menunjukan kondisi yang sangat baik. Biasanya semakian besar rasionya ssemakin bagus juga penilaianpara penanam modal terhadap perusahaan tersebut. Hasil perbandiang dari rasio ini sering pula dipakai untuk alternatif unutk menentukan harg/nilai saham, karena secara teoritis ada hubungan yang tergambar antara nilai pasar suatu saham dengan nilia bukunya.

Harga saham ynag dipakai sebgai varibel $\mathrm{Z}$ pada penelitian ini dipasar modal seringkali harganya naik turun dari waktu kewaktu. Fluktuiasi harga pasar saham tersebut akan mempengaruhi diantara kekuatan permintaan dan peawaran. Jika jumlah saham yang ditawarkan lebih besar dari jumlah ynag diminta, seringkali kondisi ini akan mempengaruhi nilai kurs saham menurun. Dan sebaliknya jika juamklah saham yang diminta melebihi dari jumlah saham yang diatawarkan maka kondisi ini sering mempengruhi harga saham dengan 
kecendrungan naik. Menurut Nainggolan (2008) “ hal-hal yang penting dan merupakan faktor makro atau pasar yang dapat menyebabkan fluktuasi (naik turun) harga suatu saham adalah tingkat inflasi dan suku bunga, kebijakan keuangan dan fiskal,kondisi perekonomian dan kondisi bisnis internasional".

Berdasarkan dari hasil pengolahan data pada obyek perusahaan Indonesia yan terdaftar di BEJ ditemukan serta didapatkan data untuk CR, DPR, ROE dan PBV serta HS adalah sebagaiberikut:

Tabel 1.1

Nilai Variabel-Variabel Perusahaan Indonesia

\begin{tabular}{|c|c|c|c|c|c|c|}
\hline \multirow{2}{*}{ NAMA_PERUSAHAAN } & \multirow{2}{*}{ TAHUN } & \multicolumn{5}{|c|}{ Variabel Penelitian } \\
\hline & & $\overline{\mathrm{CR}}$ & ROE & DPR & PBV & $\mathrm{HS}$ \\
\hline 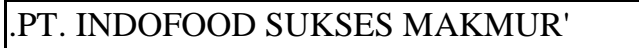 & 2011 & 1.9 & 0.2 & 0.4 & 46.0 & $4,600.0$ \\
\hline 'PT. INDOFOOD SUKSES MAKMUR' & 2012 & 1.0 & 0.1 & 0.5 & 58.5 & $5,850.0$ \\
\hline 'PT. INDOFOOD SUKSES MAKMUR' & 2013 & 1.7 & 0.1 & 1.1 & 66.0 & $6,600.0$ \\
\hline 'PT. INDOFOOD SUKSES MAKMUR' & 2014 & 1.8 & 0.1 & 0.4 & 67.5 & $6,750.0$ \\
\hline 'PT. INDOFOOD SUKSES MAKMUR' & 2015 & 1.7 & 0.1 & 0.8 & 51.8 & $5,175.0$ \\
\hline 'PT. INDOFOOD SUKSES MAKMUR' & 2016 & 1.5 & 0.1 & 0.4 & 79.3 & $7,925.0$ \\
\hline 'PT. INDOFOOD CBP SUKSES MAKMUR & 2011 & 2.9 & 0.2 & 0.3 & 52.0 & $5,200.0$ \\
\hline 'PT. INDOFOOD CBP SUKSES MAKMUR & 2012 & 2.8 & 0.2 & 0.5 & 81.0 & $8,100.0$ \\
\hline 'PT. INDOFOOD CBP SUKSES MAKMUR & 2013 & 2.4 & 0.2 & 0.5 & 109.0 & $10,900.0$ \\
\hline 'PT. INDOFOOD CBP SUKSES MAKMUR & 2014 & 2.2 & 0.2 & 0.4 & 131.0 & $13,100.0$ \\
\hline 'PT. INDOFOOD CBP SUKSES MAKMUR & 2015 & 2.3 & 0.2 & 0.9 & 134.8 & $13,475.0$ \\
\hline PT. INDOFOOD CBP SUKSES MAKMUR & 2016 & 2.4 & 0.2 & 0.8 & 85.8 & $8,575.0$ \\
\hline 'PT. MAYORA INDAH & 2011 & 2.2 & 0.2 & 0.2 & 24.4 & $12,214.0$ \\
\hline 'PT. MAYORA INDAH & 2012 & 2.8 & 0.2 & 0.1 & 33.6 & $16,800.0$ \\
\hline 'PT. MAYORA INDAH & 2013 & 2.4 & 0.3 & 0.2 & 52.0 & $26,000.0$ \\
\hline 'PT. MAYORA INDAH & 2014 & 2.1 & 0.1 & 0.5 & 41.8 & $20,900.0$ \\
\hline |'PT. MAYORA INDAH & 2015 & 2.4 & 0.2 & 0.1 & 61.0 & $30,500.0$ \\
\hline 'PT. MAYORA INDAH & 2016 & 2.3 & 0.2 & 0.2 & 3.3 & $1,645.0$ \\
\hline 'PT. FAST FOOD INDONESIA TBK' & 2011 & 1.8 & 0.3 & 0.9 & 20.6 & $2,296.0$ \\
\hline 'PT. FAST FOOD INDONESIA TBK' & 2012 & 1.8 & 0.2 & 0.2 & 23.0 & $2,792.0$ \\
\hline 'PT. FAST FOOD INDONESIA TBK' & 2013 & 1.7 & 0.1 & 0.3 & 27.9 & $1,900.0$ \\
\hline
\end{tabular}




\begin{tabular}{|l|r|r|r|r|r|r|}
\hline PT. FAST FOOD INDONESIA TBK' & 2014 & 2.1 & 0.1 & 0.4 & 19.0 & $2,100.0$ \\
\hline 'PT. FAST FOOD INDONESIA TBK' & 2015 & 1.3 & 0.1 & 0.6 & 21.0 & $1,150.0$ \\
\hline 'PT. FAST FOOD INDONESIA TBK' & 2016 & 1.8 & 0.1 & 0.3 & 11.5 & $1,500.0$ \\
\hline PT. NIPPON INDOSARICORPINDO . Tbk & 2011 & 1.3 & 0.2 & 0.2 & 33.3 & $3,325.0$ \\
\hline PT. NIPPON INDOSARICORPINDO . Tbk & 2012 & 1.1 & 0.2 & 1.0 & 69.0 & $6,900.0$ \\
\hline PT. NIPPON INDOSARICORPINDO . Tbk & 2013 & 1.1 & 0.2 & 1.2 & 51.0 & $1,020.0$ \\
\hline PT. NIPPON INDOSARICORPINDO . Tbk & 2014 & 1.4 & 0.2 & 0.4 & 69.3 & $1,385.0$ \\
\hline PT. NIPPON INDOSARICORPINDO . Tbk & 2015 & 2.1 & 0.2 & 0.5 & 63.3 & $1,265.0$ \\
\hline PT. NIPPON INDOSARICORPINDO . Tbk & 2016 & 3.0 & 0.2 & 0.2 & 80.0 & $1,600.0$ \\
\hline 'PT. TUNAS BARU LAMPUNG. Tbk' & 2011 & 1.4 & 0.2 & 0.2 & 4.7 & 410.0 \\
\hline 'PT. TUNAS BARU LAMPUNG. Tbk' & 2012 & 1.6 & 0.1 & 0.4 & 3.9 & 590.0 \\
\hline 'PT. TUNAS BARU LAMPUNG. Tbk' & 2013 & 1.1 & 0.0 & 0.5 & 3.8 & 470.0 \\
\hline 'PT. TUNAS BARU LAMPUNG. Tbk' & 2014 & 1.1 & 0.0 & 0.1 & 6.0 & 470.0 \\
\hline 'PT. TUNAS BARU LAMPUNG. Tbk' & 2015 & 1.2 & 0.2 & 0.6 & 4.1 & 755.0 \\
\hline 'PT. TUNAS BARU LAMPUNG. Tbk' & 2016 & 1.1 & 0.2 & 0.2 & 7.9 & 990.0 \\
\hline AVG & & 1.8 & 0.2 & 0.5 & 47.2 & $6,534.1$ \\
\hline
\end{tabular}

Sumber: BEJ \& Bursa Efek Malaysia, diolah 2017

Sedangkan data yang didapatkan dan diolah pada obyek perusahaan Malaysia yang didapatkan data untuk CR, DPR, ROE dan PBVserta Harga Saham adalah sebagai berikut:

Tabel 1.2

Nilai Variabel-Variabel Perusahaan Malaysia

\begin{tabular}{|l|c|c|c|c|c|c|}
\hline \multirow{2}{*}{ NAMA_PERUSAHAAN } & \multirow{2}{*}{ TAHUN } & \multicolumn{4}{|c|}{ VARIBEL PENELITIAN } \\
\cline { 4 - 7 } & & CR & ROE & DPR & PBV & HS \\
\hline BERJAYA FOOD BERHAD (5196) & 2011 & 4.21 & 0.20 & 0.42 & 1.52 & 0.76 \\
\hline BERJAYA FOOD BERHAD (5196) & 2012 & 3.15 & 0.19 & 0.64 & 2.40 & 1.20 \\
\hline BERJAYA FOOD BERHAD (5196) & 2013 & 2.24 & 0.12 & 0.64 & 2.96 & 1.48 \\
\hline BERJAYA FOOD BERHAD (5196) & 2014 & 1.70 & 0.12 & 0.44 & 6.00 & 3.00 \\
\hline BERJAYA FOOD BERHAD (5196) & 2015 & 0.84 & 0.04 & 1.35 & 4.10 & 2.05 \\
\hline BERJAYA FOOD BERHAD (5196) & 2016 & 0.53 & 0.05 & 0.86 & 3.14 & 1.57 \\
\hline
\end{tabular}




\begin{tabular}{|c|c|c|c|c|c|c|}
\hline HUP SENG INDUSTRIES BERHAD (5024) & 2011 & 2.78 & 0.13 & 0.97 & 0.26 & 0.26 \\
\hline HUP SENG INDUSTRIES BERHAD (5024) & 2012 & 4.66 & 0.21 & 1.22 & 0.44 & 0.44 \\
\hline HUP SENG INDUSTRIES BERHAD (5024) & 2013 & 2.98 & 0.24 & 0.72 & 1.03 & 1.03 \\
\hline HUP SENG INDUSTRIES BERHAD (5024) & 2014 & 2.50 & 0.25 & 0.88 & 0.93 & 0.93 \\
\hline HUP SENG INDUSTRIES BERHAD (5024) & 2015 & 2.50 & 0.33 & 0.80 & 1.25 & 1.25 \\
\hline HUP SENG INDUSTRIES BERHAD (5024) & 2016 & 3.04 & 0.27 & 0.65 & 1.10 & 1.10 \\
\hline KAWAN FOOD BERHAD (7216) & 2011 & 3.80 & 0.13 & 0.12 & 0.92 & 0.46 \\
\hline KAWAN FOOD BERHAD (7216) & 2012 & 3.49 & 0.11 & 0.10 & 0.84 & 0.42 \\
\hline KAWAN FOOD BERHAD (7216) & 2013 & 3.98 & 0.12 & 0.13 & 1.50 & 0.75 \\
\hline KAWAN FOOD BERHAD (7216) & 2014 & 3.37 & 0.14 & 0.31 & 2.18 & 1.09 \\
\hline KAWAN FOOD BERHAD (7216) & 2015 & 3.66 & 0.15 & 0.12 & 5.46 & 2.73 \\
\hline KAWAN FOOD BERHAD (7216) & 2016 & 3.60 & 0.11 & 0.63 & 5.70 & 2.85 \\
\hline $\begin{array}{l}\text { ORIENTAL FOOD INDUSTRIES } \\
\text { HOLDING BERHAD (7107) }\end{array}$ & 2011 & 2.93 & 0.07 & 0.66 & 0.79 & 0.79 \\
\hline $\begin{array}{l}\text { ORIENTAL FOOD INDUSTRIES } \\
\text { HOLDING BERHAD (7107) }\end{array}$ & 2012 & 2.64 & 0.11 & 0.37 & 1.70 & 1.70 \\
\hline $\begin{array}{l}\text { ORIENTAL FOOD INDUSTRIES } \\
\text { HOLDING BERHAD (7107) }\end{array}$ & 2013 & 2.89 & 0.10 & 0.38 & 1.10 & 1.10 \\
\hline $\begin{array}{l}\text { ORIENTAL FOOD INDUSTRIES } \\
\text { HOLDING BERHAD (7107) }\end{array}$ & 2014 & 3.36 & 0.11 & 0.30 & 1.40 & 1.40 \\
\hline $\begin{array}{l}\text { ORIENTAL FOOD INDUSTRIES } \\
\text { HOLDING BERHAD (7107) }\end{array}$ & 2015 & 4.13 & 0.13 & 0.53 & 2.08 & 2.08 \\
\hline $\begin{array}{l}\text { ORIENTAL FOOD INDUSTRIES } \\
\text { HOLDING BERHAD (7107) }\end{array}$ & 2016 & 3.37 & 0.15 & 0.94 & 1.37 & 1.37 \\
\hline $\begin{array}{l}\text { DUTCH LADY MILK INDUSTRIES } \\
\text { BERHAD }\end{array}$ & 2011 & 2.40 & 0.42 & 0.43 & 5.40 & 5.40 \\
\hline $\begin{array}{l}\text { DUTCH LADY MILK INDUSTRIES } \\
\text { BERHAD }\end{array}$ & 2012 & 1.91 & 0.57 & 1.35 & 6.44 & 6.44 \\
\hline $\begin{array}{l}\text { DUTCH LADY MILK INDUSTRIES } \\
\text { BERHAD }\end{array}$ & 2013 & 1.52 & 0.74 & 1.20 & 7.14 & 7.14 \\
\hline $\begin{array}{l}\text { DUTCH LADY MILK INDUSTRIES } \\
\text { BERHAD }\end{array}$ & 2014 & 1.44 & 0.70 & 1.28 & 7.40 & 2.40 \\
\hline
\end{tabular}




\begin{tabular}{|l|c|c|c|c|c|c|}
\hline $\begin{array}{l}\text { DUTCH LADY MILK INDUSTRIES } \\
\text { BERHAD }\end{array}$ & 2015 & 1.27 & 0.90 & 1.00 & 7.76 & 7.76 \\
\hline $\begin{array}{l}\text { DUTCH LADY MILK INDUSTRIES } \\
\text { BERHAD }\end{array}$ & 2016 & 1.20 & 0.90 & 0.94 & 8.56 & 8.56 \\
\hline \multicolumn{1}{|c|}{ AVG } & & $\mathbf{2 . 7}$ & $\mathbf{0 . 3}$ & $\mathbf{0 . 7}$ & $\mathbf{3 . 1}$ & $\mathbf{2 . 5}$ \\
\hline
\end{tabular}

Sumber: Bursa Efek Indonesia \& Bursa Malaysia

\section{TELAAH LITERATUR DAN PENGEMBANGAN HIPOTESIS}

Untuk membandingan antara Aktiva Lancar dengan kewajiban lancarnya yang dimiliki oleh perusahan maka dapat menggunkan Current Ratio.yang dinyatakan sebagai kesanggupan perusahaan untuk menunaikan seluruh kewajiban jangka pendeknya. Current Ratio/Rasio Lancar dapat di hitung dengan rumus :

\section{${ }^{\prime}$ Current Ratio' $=\quad$ Current Asset}

\section{Current Liability}

Menurut Kasmir (2012:134) "Rasio lancar atau current ratio merupakan perbandingan yang digunakan dalam melihat kemampuan perusahaan untuk membayar seluruh kewajiban atau utang jangka pendek yang segera jatuh tempo atau pada saat ditagih secara keseluruhan". Makna lainnya yaitu seberaapa baanyak harta lancra yaang terseedia mamapu melunasi hutang Jangaka pendek atau kewajiban ayang akan segera jatuh tempo. Catatan penting dari rasio ini adalah semakin tinggi nilai prosentase rasio Liquiditas adalah semakin baik artinya kemampuan perushaan dalam mememuhi kewajibannya semakin baik.

Divident Payout Ratio menurut pendapat Muhadi (2013:65) "Dividend Payout Ratio merupakan rasio yang menggambarkan besarnya proporsi dividen yang dibagikan terhadap pendapatan bersih perusahaan”. Pendapat lain yaitu menurut Halim dan Hanafi (2009:86) dikemukakan bahwa " Dividend Payout Ratio merupakan rasio pembayaran dividen yang melihat bagian earnings 
(pendapatan) yang dibayarkan sebagai dividen kepada investor. Bagian lain yang tidak dibagikan akan diiinvestasikan kembali ke perusahaan". Pendapat lain dikemukakan Hartono (2008 : 371), "Dividend payout ratio diukur sebagai dividen yang dibayarkan dibagi dengan laba yang tersedia untuk pemegang saham umum". Pendapat dari Atmaja (2008:85) dijelaskan bahwa "persentase dividen yang dibagikan dari laba setelah pajak disebut Dividend payout ratio". Dari kumpulan pendapat-pendapat yang dikemukakan, dapat ditarik kesimpulkan bahwa Dividen Payout Ratio adalah bagian keuntungan atau laba bersih perusahaan dalam satu periode akuntansi yang dibagikan kepada pemegangg saham. DPR adalah model atau indikasi yang digunakan dalam penilaian saham dan model dalam mengkalkulasi perkiraan jumlah deviden yang akan dibayarakan dimasa mendatang.

Menurut Darmadji (2006) "Rasio pembayaran dividen (dividend payout ratio) merupakan perbandingan dividend per share terhadap laba perusahaan atau earning per share". Maka untuk menghitung pembayaran deviden perlembar saham dapat menggunkan rumus sebagai berikut (Van Home dan Wachowicz, 2005):

\begin{tabular}{|l|l|}
\hline Deviden Payout Ratio $=$ & $\begin{array}{l}\text { Deviden per Share } \\
\text { Earning per Share }\end{array}$ \\
\hline
\end{tabular}

Perbandingan yang dipakai dalam mengukur kemampuan modal sendiri unutk menghasilkan laba bagi selueruh pemegang saham biasa mauupun saham preferen diseebut Return On Equity (ROE). Menurut Kasmir (2012: 204) "Return On Equity (ROE) adalah rasio untuk mengukur laba bersih sesudah pajak (earning after tax) dengan modal sendiri”. Menurut Irham Fahmi (2012:98) “ Return On Equity adalah rasio yang digunakan untuk mengukur sejauh mana suatu perusahaan mempergunakan sumber daya yang dimiliki untuk mampu memberikan laba atas ekuitas yang dimiliki”. Rasio ini dapat dihitung dengan rumus yaitu: 


\section{'Return On Equity = Net Income / Earnig After Taxt (EAT)}

Total Equity Saham

Naik turun harga saham akan sangat mempengaruhi rasio PVB karena ini terkait erat dengan harga saham disuatu perusahaan, jika PBV dengan rasio tinbggi, maka menggambarkan harga saham yang tinggi begitu pula jika kejadian sebaliknya semakin rendah nilai PBV semakin rendah nilai jual saham perusahaan tersebut. Perusahaan yang nilai harga pasar sahamnya selalu tinggi memberikan pertanda kemungkinan perusahaan tumbuh dengan baik. Menurut Brigham dan Ehrhardt (2001 : 67) "cara untuk menghitung Price To Book Value dihitung dengan memperbadingkan antara harga saham dengan nilai buku saham":

$$
\begin{aligned}
& \text { 'Price to Book Value = ; } \text { Harga Saham x } 100 \% \\
& \text { 'Nilai Buku Saham }
\end{aligned}
$$

Menurut Sartono (2008 : 70) "Harga saham terbentuk melalui mekanisme permintaan dan penawaran di pasar modal. Apabila suatu saham mengalami kelebihan permintaan, maka harga saham cenderung naik. Sebaliknya, apabila kelebihan penawaran maka harga saham cenderung turun”. Sedangkan menurut Jogiyanto (2008:167) "harga saham adalah harga suatu saham yang terjadi di pasar bursa pada saat tertentu yang ditentukan oleh pelaku pasar dan ditentukan oleh permintaan dan penawaran saham yang bersangutan di pasar modal".

Berdasarkasn latar belakang, perumusan masalah dan tujuan penelitian, maka hipotesis dalam penelitian ini adalah sebgai berikut:

Ho1 : Diduga tidak terdapat pengaruh CR terhadap PBV.

Ha1 : Diduga terdapat pengaruh $C R$ terhadap $P B V$

Ho2 : Diduga tidak terdapat pengaruh DPR terhadap PBV 
Ha2 : Diduga terdapat pengaruh DPR terhadap $P B V$

Ho3 : Diduga tidak terdapat pengaruh ROE terhadap PBV

Ha3 : Diduga terdapat pengaruh ROE terhadap $P V P$

Ho4 : Diduga tidak terdapat pengaruh CR, DPR, ROE terhadap PBV

Ha4 : Diduga terdapat pengaruh $\mathrm{CR}, \mathrm{DPR}, \mathrm{ROE}$ terhadap $P B V$

Ho5 : Diduga tidak ada pengaruh PBV terhadap Harga Saham

Ha5 : Diduga ada pengaruh PBV terhadap Harga Saham

\section{METODOLOGI PENELITIAN}

Laporan keuangan perusahaan sebanyak 16 perusahaan yang terindeks di BEJ dan 10 perusahaan yang terindeks di Bursa Malaysia, yang secara konsisten mengeluarkan laporan keuangan mulai 2011 hingga 2016. Didalam penelitian ini teeknik peengambilan sampel meneggunakan teknik/metode puposeive sampling yaitu tehnik penentuan sampling dengan pertimbangan tertentu. Atas dasar kesesuaian data dan karakteristik sampel ynag ditetapkan, maka didapatkan data 6 perusahaan Indonesia dan 5 perusahaan Malaysia. Pengujian Kesesuaian Model pada penelitian ini dengan regresi data panel Common Effect, Fixed Effect dan Random Effect, Common Effect, sedangkan model pemilihan data dengan menggunakan Uji Chow dan Uji Hausman. Pada penelitian ini teknis analisis data menggunakan Analisi Rgeresi Linier Beerganda dengan menggunkan program Eviews versi 18.

\section{HASIL PENELITIAN DAN PEMBAHASAN}

\section{Perusahaan Indonesia}

\section{Uji T}

\section{Hasil Uji CR terhadap PBV}

Pengujian hipotesis pengaruh variabel $C R$ terhadap $P B V$ dengan analisis regresi linier berganda. Nilai $\mathrm{df}=(\mathrm{n}-\mathrm{k})$ dengan standar deviasi $5 \%$ dimana $\mathrm{n}=36$ dan $\mathrm{k}=3$ adalah " $\mathrm{df}=(36-3)=33$ ", maka $\mathrm{t}$-tabel $(0,05 ; 33)=$ 2,03452. Hasil pengujian t-hitung $=0.91151$, jadi nilai perbandingan $\mathrm{t}-$ tabel $(0.091151<2,03452)$ dengan nilai probability $C R=0.9280$. Tanda 
positif yang ditunjukan oleh nilai koefisien variabel CR menunjukan bahwa $C R$ dan PBV memiliki hubungan searah. Semakin tiinggi nilai $\mathrm{CR}$, maka nilai PBV akan semakin meningkat dan begitu sebaliknya, semakin merendah nilai $\mathrm{CR}$ maka nilai PBV akan semakin menurun. Standar probability pada penelitian ini 0,05 atau $5 \%$. Nilai probability untuk uji CR terhadapa $\mathrm{PBV}=0.9280$ artinya lebih besar dari standar 0,05 maka dapat diartikan Ho diterima dan $\mathrm{H} 1$ ditolak. Hal ini menunjukan bahwa tidak terdapat pengaruh positif dan signifikan antara CR terhadap variabel PBV.

\section{Hasil Uji DPR terhadap PBV}

Hasil pengolahan data dengan Eviews, didapat hasil -perhitungannya adalah -0.109790 . Hasil $\mathrm{t}$-tabel $\mathrm{n}=36$ dan $\mathrm{k}=3$ adalah $\mathrm{df}=(36-3)=33$ sama dengan $(0,05 ; 33)=2,03452$ sehingga didapat perbandingan yaitu t-hitung lebih kecil dari t-tabel $(-0.109790<2,03452)$. Nilai probabilitas DPR = 0.9133, sedangkan standar probabilitas 0.05 sehingga didapat nilai probabilitas DPR $=0.9133>0,05$, hasil demikian dapat disimpulkan bahwa H0 daapat diterima dan $\mathrm{H} 1$ dinyatakan ditolak. Ini menunjukan $D P R$ tidak memiliki pengaruh negatif yang signifikan terhadap $P B V$ dan kedua variabel memiliki hubungan yang tidak searah yang dinyatakan dengan tanda minus pada hasil ujinya

\section{Hasil Uji ROE terhadap PBV}

Dari hasil pengujian pengaruh ROE terhadap PBV dengan analisis regresi linier berganda didapatkan t-hitung ROE adalah 0.113457, tanda positif artinya memiliki hubungan searah, artinya jika nilai $R O E$ meningkat maka nilai PBV juga makin meningkat dan begitupula sebaliknya. Hasil $\alpha=5 \%, \mathrm{n}=36$ dan $\mathrm{k}=3$ maka $\mathrm{df}=(\mathrm{n}-\mathrm{k})$ pada $\mathrm{t}$-tabel adalah $\mathrm{df}=(36-3)=33$, maka t-tabel $(0,05 ; 33)=2,03452$ maka didapatkan perbandingan yaitu $\mathrm{t}$ hitung lebih kecil dari t-tabel $(0.113457<2,03452)$. Nilai probability ROE $=0.9105$ dan standar nilai probability 0,05 atau $5 \%$ sehingga didapat perbandingan nilai probability $\mathrm{ROE}=0.9105>$ ' 0,05 , artinya $\mathrm{H} 0$ diterima 
dan $\mathrm{H} 1$ ditolak. Hal ini dapat diartikan bahwa $R O E$ tidak mempunyai pengaruh secara signifikn terhadap PBV.

\section{Uji F}

\section{Hasil Uji CR, RPR dan ROE terhadap PBV}

Berdasarkan hasil perhitungan dengan menggunkan program eviews versi 8.0 nilai $\mathrm{F}$ hitung yang dihasilkan yaitu sebesar 14.55898, sementara untuk mencari f tabel dengan $\alpha=5 \%$ (0.05), jumlah sampel 36, jumlah variabel $\mathrm{k}=5$, maka didapat 'df $1=(\mathrm{k}-1)=(5-1)=4$ (kolom 4) dan 'df2 $=(\mathrm{n}-$ $k)=36-5)=31$ (baris 31), didapat $f$ tabel sebesar 2.68. Dengan demikTian F hitung > F tabel $(14.55898>2.68)$ maka dapat diambil kesimpulan bahwa variabel-variabel independen secara simultan memepunyai pengaruh terrhadap variabel dependen. Dari hasil pebgujian didapat nilai probabilitas yaitu sebesar 0.00000 yang nilainya. Maka dapat disimpulkan CR, DPR dan ROE mempunyai pengaruh yang signifikan terhadap PBV secara simultan untuk perusahaan industri makanan yang teregristrasi pada Bursa Efek Jakarta.

\section{Hasil Uji Determinasi}

Kemampuan model dalam mempengaruhi variabel dependen dapat di uji dengan formula yang disebut Uji Koefisien Determinasi $\left(\mathrm{R}^{2}\right)$. Hasil analisis dalam penelitian ini diperoleh niali $\mathrm{R}^{2}=0.811810=81.18 \%$, artinya kekuatan/kemampaun variabel-variabel independen mampu menjelaskan atau mempengaruhi Variiabel dependen sebesar 81.18\%, sedangkan selebihnya $18.82 \%$ dijelaskna oleh unsur variabel yang lain diluar variabel ynag diteliti. Hasil koefisien determinasi gabungan persamaan striktural $\mathrm{R} \frac{2}{m}=1-\left(\mathrm{e}_{1}^{\frac{2}{2}} \mathrm{e}_{2}^{\frac{2}{2}} \mathrm{e}_{p}^{\frac{2}{p}}\right)$ yaitu $\mathrm{R} \frac{2}{m}=1-\left(0.81181^{2} \mathrm{x}\right.$ $\left.0.18819^{2}\right)$, diperoleh nilai $0.97666=97.67 \%$, artinya $97.67 \%$ informasiinformasi yang termuat didalam penelitian mampu dijelaskan oleh model 
dan sebesar $2,33 \%$ sisanya dipengaruhi oleh variabel lain yang tidak diteliti.

\section{Uji Varaibel Y terhadap Z}

\section{Hasil Uji Pengaruh PBV terhadap HS}

Hasil yang didapat untuk t-hitung varaibel $P B V$ adalah 6.181000. Nilai yang bertanda positif/plus pada koefisien variabel ini menunjukan bahwa $P B V$ dan Harga Saham memiliki hubungan yang searah. Semakin meningkat nilai PBV maka Harga Saham juga akan makin meningkat dan begitu juga sebaliknya. Hasil t tabel dengan standar probabilitas 5\% dengan jumlah $\mathrm{n}=36$ dan $\mathrm{k}=1$ dengan rumus $\mathrm{df}(\mathrm{n}-\mathrm{k})$ sama dengan $\mathrm{df}=(36-$ $1)=35$, didapatkan hasil $\mathrm{t}$ tabel $(0,05 ; 35)=2,0301$. Dari hasil tesebut dibuat perbandingan thitung dan t tabel $(6.181000>2,03011)$. Sedangkan nilai probabilitas $\mathrm{PBV}=0.0000$, dan standar probabilitas 0.05 , hasilnya probabilitas $\mathrm{PBV}=0.0000<$ standar 0.050 . Maka kesimpulannya variabel Y (PBV) pada Perusahaan Indonesia mempeunyai pengaruuh yang signifikan terhadapa variabel Z (Harga Saham)

\section{Perusahaan Malaysia}

\section{Uji T}

\section{Hasil Uji CR terhadap PBV}

Hasil dari pengujian t-hitung variabel independen CR dengan regresi linier berganda adalah -3,486956, hasil ini menunjukan bahwa antara CR dan PBV memiliki hubungan yang tidak searah, semakin mingkat nilai CR maka nilai PBV akan makin menurun begitu juga sebaliknya. Hasil t tabel untuk jumlah $n=30$ dan $k=3$ yaitu 2,05183, sehingga perbandingan $t$ hitung dan t tabel sama denga ( $3,486956>2,05183)$. Standar probabilitas paada penelitian ini 0,05 sedangkan nilai probability $C R=0.0313$, maka didapat perbandingan $=0.0315<0,05$. Dengan demikian bisa diartikan Ho ditolak dan $\mathrm{H} 1$ diterima. Dari hasil terebut menunjukan bahwa variabel $C R$ memiliki pengaruh dan signifikan terhadap variabel PBV 


\section{Hasil $U j i$ DPR terhadap PBV}

Hasil pengujian variabel independen DPR dengan program eviews adalah senilai 1.549269, hasil iini menunjukan bahwa antara DPR dan PBV memiliki hubungan yang searah yang ditunjukan dengan tanda positif pada hasilnya. Hasil $\mathrm{t}$ tabel dengan jumlah $\mathrm{n}=30$ dan $\mathrm{k}=3$ maka didapat $\mathrm{df}=(30$ $3)=27$, hasilnya dari $(0,05 ; 27)=2,05183$ sehingga didapat perbandingan yaitu antara t hitung dan $t$ tabel $=(1,549269<2,05183)$. Sedangkan nilai probability DPR $=0.1344$, dengan standar probability $5 \%=0.05$ sehingga didapat nilai perbandingan probability $\mathrm{DPR}=0.1344$ standar probabilitas 0.05. Hasil ini dapat diterjemahkan Ho diterima dan $\mathrm{H} 1$ ditolak. Hal demikian menunjukan $D P R$ tidak mempunyai pengaruh positif dan sigifikn terhadap PBV. Semakin meningkat nilai DPR maka nilai PBV akan makin bertambah pula, demikian pula sebaliknya, walupun tidak signifikan.

\section{Hasil Uji ROE terhadap PBV}

Pengujian dengan eviews didapatkan t hitung variabek ROE adalah 2.451454, dan nilai t-tabel dengan jumlah $\mathrm{n}=30$ dan $\mathrm{k}=3$ maka didapat $\mathrm{df}=(30-3)=27$ sama dengan 2,05183. Perbandingan antara thitung dan $\mathrm{t}$ tabel $=(2.451454>2,05183)$. Nilai probabilitas $\mathrm{ROE}=0.0207$, sedangkan standar probabilitas 0,05 , sehingga didapat nilai probabilitas $\mathrm{ROE}=0.0207<0.05$. Dengan mengacu pada hasi tersebut artinya Ho dtolak dan H1 dterima. Deangan demikian dapat dijelaskan bahwa ROE mempunhyai pengaruh yamg signifikan terhadap variabel PBV . Begitupun dengan nilai positif pada hasil pengujian dapt dijelaskan antara ROE dan PBV memiliki hubungan yang searah, semakin meningkat nilai $R O E$ maka

nilai PBV akan makin meningkat dan begitu sebaliknya dengan pengaruh yang signifikan. 


\section{Hasil Uji F}

\section{Hasil Uji CR, DPR dan ROE terhadap PBV}

Hasil perhitungan program Eviews didapat f-hitung yaitu sebesar 12.27125, Tanda positif yang ditunjukan oleh nilai koefisien $C R, D P R$ dan $R O E$ menunjukan bahwa $C R, D P R, R O E$ dan $P V B$ memiliki hubungan yang satu searah. Sementara untuk mencari f tabel dengan $\alpha=5 \%(0.05)$ dan rumus df1(k-1) dan df2(n-k), dengan jumlah sampel 30, jumlah variabel $\mathrm{k}$ $=5, \mathrm{df} 1=(5-1)=4($ kolom 4$)$ dan $(30-5)=25$ (baris 25$)$, maka hasil $\mathrm{f}$ hitung senilai 2.68. Perbandingan f hitugn dan f tabel (12.27125> 2.76) Hasil probabilitas f-hitung yaitu senilai 0.000003 dan standar probabilitas 0.05 sehingga didapat perbandingan nilai probability $=0.000003<$ 0,0500, ini dapat dijelaskan bahwa Ho ditolah dan H1 diterima. Dengan demikian $C R$, $D P R$ dan $R O E$ mempunyai pengaruh yang positif dan signifikan terhadap PBV pada peushaan industri makanan di Malaysia.

\section{Hasil Uji $\left(\mathbf{R}^{2}\right)$ Determinasi}

Pengujian untuk mengukur besarnya kemampuan model dapat menerangkan variabel-varibel dependen digunakan uji determinasi. Berdasarkan uji analisis determinasi diperoleh nilai $\mathrm{R}^{2}=0.796105=$ 79.61\%, artinya varibel-variabel independen mampunyai kemampuan menjelaskan atau mempengaruhi variabel dependen sebesar 79.61\%, sedangkan sisanya dipengaruhi oleh varabel lain diluar variabel yang diteliti sebesar $20,39 \%$.

\section{Uji Varaibel Y terhadap Z}

\section{Hasil Uji variabel PBV terhadap HS}

Dari hasil pengujian PBV didapat hasil t-hitung adalah 33.80530. Hasil penelusuran nilai $\mathrm{t}$ abel standar probailitas 0.05 dan rumus $\mathrm{df}(\mathrm{n}-\mathrm{k})$ dengan jumlah $\mathrm{n}=30$ dan $\mathrm{k}=1$ adalah $\mathrm{df}=(30-1)=29$, didapat nilai $(0.05 ; 29)=2.04523$. Perbandingan antara $\mathrm{t}$ hitung dan $\mathrm{t}$ tabel adalah $(33.80533>2,04523)$. Standar probabilitas 0.05 sedangkan nilai 
probabilitas $\mathrm{PBV}=0.0000$, sehingga di apatkan perbandingan probabilitas $\mathrm{PBV}=0.0000<0,05$, ini dapat diartikan Ho ditolak dan $\mathrm{H} 1$ diterima. Hasil demikian menggambarkan PBV memepunyai pengaruuh yang signifikan (kuat) terhadap variabel Haarga Saaham. Hasil positif nilai koefisien variabel PBV mengambarkan bahwa PBV dan Hargaa Sahamm memiliki hubungan yang searah. Makin tinggi nilai PBV maka makin tinggi juga nilai Harga Saham, demikian sebaliknya dengan pengaruh yang signifikan.

\section{SIMPULAN}

Dengan didasarkan pada penjelasan dan hasil pengujian pengaruh $C R$, $R O E$ dan $D P R$ terhadap $\mathrm{PBV}$ pada perusahaan Industri Makanan (survey perbandingan antara parerusahaan yang terdafttar di BEJ dan perusahaaan Malaysia yang yang teregistrsi di Bursa Efek Malysia, dapat disimpulakan sebagaiberikut :

1. Pada Perusahaan Indonesia tidak ada penagruh yang positif dan signifikan secara parsial antara CR terhadapa PBV, sedangkan pada perusahaan indutri makanan Malaysia bepengaruhyang negatif dan signifikan secra parsiall antara CR terhadap PBV.

2. Hasil pengujian pada industry makanan di Indonesia tidak berpengaruh negatif yang signifikan antara DPR terhadap $P B V$ dalam pengujian secara parsial, begitupun pada perusahaan Malaysia tidak ada pengaruh posistif yang signifikan dengan pengujian secara parsial..

3. Pada erusahaan Indonesia tidak ada penagruh yang positif dan signifikan secara parsial antara variabel ROE terhadap PBV, tetapi pada perusahaan Malaysia variabel ROE terhadap PBV secara parsial.mempunyai pengaruh positif dan signifikan.

4. Hasil pengujian secara simultan variabel CR, DPR dan ROE terhadap PBV pada perusahaan di Indonesia memiliki pengatruh positif yang signifikan, begitupun dengan perusahaan di Malaysia. Dengan nilai probabilitas = $0.000000<0,05$ 
5. Uji Regresi variabel Y terhadap variabel $\mathrm{Z}$ secara varsial, pada perusahaan Indonesia berdampak pengaruh positif yang signifikan antara PBV terhadap Harga Saham begitupun dengan perusahaan Malaysia dengan nilai probabilitas $=0.0000<$ standar probabilitasi 0,05 .

\section{REFERENSI}

Anggraini, Ratih. 2014. Analisis Pengaruh Price Earning Ratio (Per), Debt To Equity Ratio (Der), Return On Asset (Roa), Current Ratio (Cr) Dan Firmsize Terhadap Nilai Perusahaan (Pbv) Pada Perusahaan Sektor Property, Real Estate \& Building Construction Yang Terdaftar Di Bursa Efek Indonesia (Bei) Tahun 2008-2012

Annisa, Rizka dan Mochammad Chabachib. 2017. Analisis Pengaruh Current Ratio (Cr), Debt To Equity Ratio (Der), Return On Assets (Roa) Terhadap Price To Book Value (Pbv), Dengan Dividend Payout Ratio Sebagai Variabel Intervening

Brigham F. Eugence dan Houlton F. Joel 2001. Manajemen Keuangan, Jakarta: Erlangga

Cahyanigrum, Yustina Wahyu dan Tiara Widya Antikasari. 2017. Pengaruh Earning Per Share, Price To Book Value, Return On Asset, Dan Return On Equity Terhadap Harga Saham Sektor Keuangan

Campbel. 2002. Pengaruh Kepemilikan asing dan kepemilikan manajemen, Size, DER dan inventory turnover terhadap ROA pada perusahaan di Hungaria

Dominikus D.Unaradjan. 2012. Metode Penelitian Kuantitatif, Universitas Atma Jaya, Jakarta

Fakhruddin, M. Hadianto. 2001. Perangkat dan Model Analisis Investasi di Pasar Modal. Jakarta: Gramedia.

Fatmawati, Noni. 2015. Pengaruh Debt to Equity Ratio, Return of Asset, Net Profit Margin dan Current Ratio tehadap Perusahaan Manufature Yang Terdaftar di Bursa Efek Indinesia (BEI) 
Ghozali, Imam. 2013. "Aplikasi Analisis Multivariate dengan Program SPSS”. Semarang: Badan Penerbit UNDIP

Hamduh, M. Hanafi. 2005. “Analisa Laporan Keuangan”. Edisi Kedua. Yogyakarta: UPP AMP YKPN.

Hartono, Jogiyanto. 2000. Teori Portofolio dan Analisis Investasi. Yogyakarta: BPFE.

Hasibuan, Melayu. 2014. "Manajemen Dasar, Penegertian dan Masalah". Edisi Revisi,. Jakarta: Bumi Aksara.

Hidayati, Eva Eko. 2010. Analisis Pengaruh DER, DPR, ROE Dan Size Terhadap PBV Perusahaan Manufaktur Yang Listing Di BEI Periode 2005-2007

Husnan, Suad. \& Pudjiastuti, Enny. 2006. "Dasar-dasar Manajemen Keuangan”. Edisi Kelima.Yogyakarta: UPP STIM YKPN.

Iriyanto, Bambang. 1999. Dasar-Dasar Pembelanjaan Perusahaan. Edisi Lima. Yogyakarta: BPFE.

Julia, Roma Uli \& Sulardi. 2003. "Manfaat Rasio Keuangan dalam Memprediksi Perubahan Laba Perusahaan Manufaktur “

Jusup, Al Hariyono. 2005. "Dasar-dasar Akuntansi". edisi 6, jilid 2. Yogyakarta: Sekolah Tinggi Ilmu Ekonomi YKPN.

Yogyakarta: Sekolah Tinggi Ilmu Ekonomi, YKPN.

Kasmir (2010). “Pengantar Manajemen Keuangan”. Edisi 1 cetakan 2. Jakarta: Kencana Prenada Media Group, . 2010. Analisis Laporan Keuangan, Edisi Pertama. Jakarta: Penerbit Raja Grafindo Persada. 2015. “Analisis Laporan Keuangan”. Jakarta: PT. Raja Grasindo Persada.

Keown. 2004. "Manajemen Keuangan Prinsip-prinsip dan Aplikasi, Edisi 9, Jakarta: Indeks.

Manurung, A. H., 2007. Cara Menilai Perusahaan, Jakarta: PT. Elex Media Komputindo 
Mardiana, Sri. 2017. Analisis ROA, Pertumbuhan Laba dan DER terhadap Retrn Saham dan Dampaknya Terhadapa Nilai Perusahaan

Moh. Nazir. 2008. "Metode Analisis Penelitian Kuantitatif dan Kualitatif". Jakarta: Penerbit Erlangga.

Nainggolan, Susan. 2008. Pengaruh Variabel Fundamental Terhadap Harga Saham Perusahaan Manufaktur yang Terdaftar di Bursa EfekIndonesia”, Tesis. Universitas Sumatera Utara, Medan.

Nasehah, Durrotun dan Endang Tri Widyarti. 2012. Analisis Pengaruh ROE, DER, DPR, Growth dan Firm Size terhadap PBV (Studi Kasus Pada Perusahaan Manufaktur Yang Listed Di BEI (Periode Tahun 20072010)

Nurmalasari, Ifa. 2016. Analisis Cuurent Ratio, ROE, DER dan Pertumbuhan Pendapatan Berpengaruh terhadap Return Saham dan DPR pada Perusahaan Pertambanan di Bursa Efek Indonesia 20101-2014

Riduwan. 2013. “Metode dan Teknik Menyusun Tesis”, Edisi Kesepuluh. Bandung: Alfabeta,

S Munawir. 2010. "Analisa Laporan Keuangan”. Yogyakarta: Liberty

Suad, Husnan dan E. Pudjiastuti. 2004. "Dasar-dasar Manajemen Keuangan”, Edisi keempat. Y ogyakart: UPP AMP YKPN,.

Sugiyono. 2008. "Metode Penelitian Bisnis". Edisi keduabelas. Bandung Alfabeta.

2014. "Metode Penelitian Kombinasi (Mixed Methods). Bandung Alfabeta.

Susilo, Yosua Eko. 2014. Pengaruh ROA, ROE, PBV, PER, NPM, OPM Terhadap Harga Saham Perusahaan Perbankan Pada Tahun 2008 2011

Swastha, Basu. 2004. "Manajemen Pemasaran Modern". Liberty. Yogyakarta

Wulandari, Anggi Ayu. Pengaruh Earning Per Share (Eps) Dan Price To Book Value Terhadap Harga Saham (Studi Kasus Pada Sektor Pertambangan Batubara Yang Terdaftar Di Bei Periode 2009-2012) 